\title{
UPAYA SATUAN POLISI PAMONG PRAJA DALAM MEWUJUDKAN KETENTRAMAN MASYARAKAT DAN KETERTIBAN UMUM DI BATANG KAPAS
}

\author{
Okma Sandra, Suryanef, Henni Muchtar \\ Program Studi Pendidikan Pancasila dan Kewarganegaraan \\ Fakultas Ilmu Sosial \\ Universitas Negeri Padang \\ E-Mail:okmasandra96@gmail.com
}

\begin{abstract}
Public tranquility and public order are a basic need of the city, as stipulated in Regional Regulation No. 1 of 2016 in the South Coastal District. But the fact shows that there are still many problems that arise as a result of violations of public peace and public order, such as those that occur in the cotton trunk area where most loose livestock are found throughout 2017. Therefore, the role of Satpol PP is needed in tackling loose livestock issues. This study aims to describe the form of Satpol PP efforts in controlling livestock in the cotton trunk area, constraints encountered when carrying out enforcement activities and solutions that must be done in overcoming the problems that occur. The method used in this study is qualitative. The results showed that the South Coast Civil Service Police Unit had carried out various efforts to control such as preventive, repressive and enforcement of penalties in the form of fines, but had not brought maximum results.
\end{abstract}

Keywords: peace, order, civil service police unit

\begin{abstract}
Abstrak
Ketentraman masyarakat dan Ketertiban umum merupakan suatu kebutuhan dasar kota, sebagaimana yang diatur dalam Peraturan Daerah No 1 tahun 2016 di Kabupaten Pesisir Selatan. Namun faktanya menunjukkan bahwa masih banyak persoalan yang muncul akibat dari pelanggaran ketentraman masyarakat dan ketertiban umum, seperti yang terjadi di daerah Batang Kapas dijumpai ternak lepas paling banyak sepanjang tahun 2017. Oleh karena itu perlu adanya peran Satpol PP dalam menanggulangi persoalan ternak lepas. Penelitian ini bertujuan untuk mendeskripsikan bentuk upaya Satpol PP dalam penertiban ternak di daerah Batang Kapas, kendala yang ditemui saat melakukan kegiatan penertiban serta solusi yang harus dilakukan dalam menanggulangi persoalan yang terjadi. Adapun metode yang digunakan dalam penelitian ini adalah kualitatif. Hasil penelitian menunjukkan bahwa Satuan Polisi Pamong Praja Pesisir Selatan telah melakukan berbagai upaya penertiban seperti preventif, represif dan penegakkan hukuman berupa denda, namun belum membawa hasil yang maksimal.
\end{abstract}


Kata kunci: ketentraman, ketertiban, satuan polisi pamong praja.

\section{PENDAHULUAN}

Hakikatnya kebijakan publik dijadikan sebagai salah satu solusi penyelesaian masalah yang berkembang di kehidupan masyarakat seperti kemiskinan, pelayanan publik yang buruk bahkan menyangkut dengan persoalan ketentraman masyarakat dan ketertiban umum. Berdasarkan Undang-Undang Nomor 23 Tahun 2014 tentang pemerintahan daerah pasal 12 ayat 1 menjelaskan bahwa ketentraman masyarakat dan ketertiban umum merupakan suatu kebutuhan dasar kota. Oleh karena itu setiap pemerintah daerah yang ada di Indonesia berupaya untuk melakukan pengaturan tersebut. Sebagai wujud nyata dari pemerintah kabupaten Pesisir Selatan telah membentuk Peraturan Daerah Nomor 1 Tahun 2016, sekaligus dijadikan sebagai aturan dasar dari adanya realisasi kebijakan publik yang ada di kabupaten Pesisir Selatan.

Salah satu persoalan yang meyangkut ketentraman masyarakat dan ketertiban umum di daerah pesisir selatan khususnya pada kecamatan Batang Kapas menunjukkan bahwa masih banyak ternak yang berkeliaran sampai ke jalan umum, sehingga dapat mengganggu jalannya aktivitas masyarakat termasuk pengguna jalan lainnya. Padahal sudah ditetapkan aturan, namun faktanya masih banyak terjadi pelanggaran aturan oleh pemilik ternak yang membiarkan hewan ternaknya lepas. Instrumen pengaturan tersebut adalah Peraturan Daerah No 1 Tahun 2016 Tentang Ketentraman Masyarakat dan Ketertiban Umum Pasal 41 menyangkut Penertiban Ternak di Kabupaten Pesisir Selatan pada poin 1 menjelaskan

1) Hewan ternak yang lepas pada jalur hijau dan fasilitas umum akan langsung dilakukan penangkapan dan kepada pemilik dikenakan denda sebagai berikut: a) Kambing dan sejenisnya dengan segala ukuran dikenakan denda sebesar Rp. 100.000,- (seratus ribu rupiah) per ekor per hari; b) Sapi dan sejenisnya dengan segala ukuran dikenakan denda sebesar Rp. 250.000,- (dua ratus lima puluh ribu rupiah) per ekor per hari; c) Batas waktu pengenaan denda paling lama 7 (tujuh) hari setelah penangkapan dan jumlah denda dikalikan lama hari penangkapan; d) Denda penangkapan disetorkan oleh pemilik ke kas daerah; e) Bukti setoran menjadi dasar bagi pemilik untuk tebusan pengambilan ternak.

Berdasarkan aturan yang dipaparkan menunjukkan dengan jelas bahwa adanya peraturan yang melarang ternak berkeliaran sampai ke jalan raya. Namun peraturan daerah tersebut belum bisa terlaksana dengan baik sebagaimana mestinya. Apalagi semenjak Peraturan daerah itu jadi lembaran daerah masih banyak warga yang tidak mematuhinya. 
Sehubungan dengan hal tersebut aparat penegak peraturan daerah telah melakukan berbagai upaya penertiban, namun belum membawa hasil yang maksimal.

Tabel 1.: Jumlah Ternak Lepas

Kabupaten : Pesisir Selatan

Tahun Data : 2017

\begin{tabular}{|c|c|c|c|c|}
\hline NO & Kecamatan & Sapi & Kerbau & Kambing \\
\hline 1 & IV Jurai & 10 & 0 & 0 \\
\hline 2 & Batang kapas & 15 & 0 & 2 \\
\hline 3 & Sutera & 3 & 0 & 0 \\
\hline 4 & Lengayang & 5 & 1 & 0 \\
\hline 5 & Ranah Pesisir & 4 & 0 & 1 \\
\hline & Total & $\mathbf{3 7}$ & $\mathbf{1}$ & $\mathbf{3}$ \\
\hline
\end{tabular}

Sumber: Dinas Satuan Polisi Dan Pamong Praja Dan Pemadam Kebakaran Kabupaten Pesisir Selatan

Menyangkut persoalan ketentraman masyarakat dan ketertiban umum di Pesisir Selatan menunjukkan bahwa masih banyak dijumpai ternak lepas terutama di daerah Batang Kapas. Karena data menunjukkan bahwa sepanjang tahun 2017 kecamatan Batang Kapas paling banyak kasus ternak yang berkeliaran di jalan raya serta meningkatnya angka kecelakaan disana. Berdasarkan berita pesisir selatan kab.go.id yang diakses pada tanggal 10 Desember 2018 menunjukkan bahwa kasus kecelakaan lalu lintas yang terjadi di jalan kabupaten Pesisir Selatan sepanjang tahun 2017 berjumlah 227 kasus, diantaranya 111 kasus korban berasal dari kalangan pelajar. Sebanyak 40 kasus yang terjadi disebabkan oleh gangguan ternak yang lepas ke jalan raya, bahkan ternak tersebut memakan badan jalan sebagai tempat peristirahatannya sampai pada malam hari.

Ketentraman masyarakat dan ketertiban umum pada dasarnya merupakan suatu interaksi sosial yang efektif antar masyarakat maupun dengan pihak pemerintah dapat merealisasikan aktivitas secara baik dan teratur (Poerwadarminta dalam Nalle:2016). Hal ini sejalan dengan pendapat Badudu dan Zain dalam Tarigan (2017) mendefenisikan bahwa pada dasarnya masyarakat mengharapkan suatu kondisi yang aman, dan tentram dalam kehidupannya agar aktivitas yang dijalankan sesuai dengan 
koridor yang ada, tanpa adanya intervensi dari pihak lain. Pendapat lain juga dikemukakan oleh Sadjijono dalam cindra (2016) menjelaskan bahwa ketentraman merupakan suatu kondisi sosial sebagaimana yang menjadi harapan bersama masyarakat akan terwujud apabila tidak adanya gangguan-gangguan yang muncul.

Selanjutnya Gautama dalam wahyuni (2014) mengibaratkan ketertiban umum sebagai rem darurat yang ada disetiap kereta api. Para pemakainya harus berhati-hati untuk menarik rem darurat ini karena dapat membahayakan penumpang yang berada di dalamnya, artinya ketertiban umum pada hakikatnya merupakan suatu bentuk upaya untuk menjaga kondisi masyarakat secara baik sesuai dengan aturan yang ada. Hal ini sejalan dengan pendapat Soedjono Dirdjosisworo dalam cindra (2016) mendefenisikan bahwa ketertiban pada hakikatnya merupakan suatu kondisi sosial yang teratur sesuai dengan aturan atau norma yang telah ditetapkan guna dijadikan sebagai pedoman untuk menjalani aktivitas kehidupan sehari-hari. Untuk mencapai penyelenggaraan ketentraman masyarakat dan ketertiban umum perlu adanya peran sentral dari aparat pelaksana ketentraman masyarakat dan ketertiban umum seperti satuan polisi pamong praja untuk dapat mewujudkan rasa aman dan nyaman tanpa ada konflik yang muncul.

Satuan polisi Pamong Praja selalu menjadi salah satu penggerak terlaksananya ketentraman, ketertiban dan perlindungan masyarakat di suatu daerah. Dengan melihat kejadian yang terjadi akibat ulah ternak lepas, pihak satuan polisi pamong praja telah melakukan berbagai upaya penertiban seperti melakukan tindakan preventif, represif dan penegakkan hukuman berupa denda guna sebagai wujud nyata jalannya tugas yang jelas. Namun fakta dilapangan menunjukkan bahwa upaya yang dilakukan belum terlaksana secara maksimal. Hal ini disebabkan oleh minimnya kapasitas anggota satuan polisi pamong praja yang bertugas di setiap kecamatan serta ketersedian sarana dan prasarana yang terbatas menjadi faktor penghambat dari jalannya aktivitas yang dilakukan.

Artikel ini bertujuan untuk mengetahui efektifitas peran satuan polisi pamong praja dalam penertiban ternak guna mewujudkan ketentraman masyarakat dan ketertiban umum di Batang Kapas serta mendeskripsikan bentuk upaya satuan polisi pamong praja dalam penertiban ternak yang berkeliaran di daerah batang kapas, selanjutnya juga mengetahui kendala apa saja yang ditemukan saat melakukan kegiatan penertiban serta solusi yang harus dilakukan dalam menanggulangi kendala yang terjadi. Dengan demikian sangat diharapkan bahwa penelitian yang dilakukan dapat bermanfaat bagi semua pihak juga menjadi salah satu referensi yang akurat sebagai sumber belajar guna untuk pengembangan wawasan di bidang 
keilmuan tentang kebijakan publik dan hukum serta pembelajaran pada pembentukan karakter bangsa yang baik.

\section{METODE PENELITIAN}

Penelitian ini dilaksanakan dengan menggunakan metode penelitian kualitatif deskriptif. Dengan penentuan lokasi penelitian di kecamatan Batang Kapas berdasarkan pertimbangan latar belakang, waktu, biaya dan tempat. Untuk informan penulis menggunakan teknik purposive sampling. Adapun informannya adalah: pimpinan satuan polisi pamong praja, kepala seksi ketentraman masyarakat dan ketertiban umum kecamatan Batang Kapas, pemilik ternak lepas dan masyarakat Batang Kapas. Jenis data dalam penelitian ini menggunakan data primer dan data sekunder. Teknik pengumpulan data dilakukan melalui observasi, wawancara dan studi dokumentasi. Untuk uji keabsahan data, penulis menggunakan teknik trianggulasi sumber. Selanjutnya data yang diperoleh akan dianalisis melalui tahap reduksi data, penyajian data dan penarikan kesimpulan.

\section{PEMBAHASAN}

1. Upaya Satuan Polisi Pamong Praja Dalam Penertiban Ternak Di Kecamatan Batang Kapas Kabupaten Pesisir Selatan

Perkembangan ternak lepas yang ada di kawasan Pesisir Selatan khususnya Batang Kapas banyak ditemui sampai pada malam hari. Observasi yang dilakukan menunjukkan bahwa banyak persoalan yang muncul akibat gangguan ternak lepas. Selain mengganggu ketentraman dan kenyamanan masyarakat juga dapat membahayakan pengguna jalan yang melewati kawasan ini, kotoran ternak yang berserakan mengakibatkan kondisi lingkungan menjadi tidak bersih dan sehat. Di samping itu ternak semakin bebas apabila di musim panen bahkan pada saat bercocok tanam masih banyak dijumpai ternak lepas sehingga dapat menurunkan produktivitas padi para petani. Hal ini sudah menjadi sorotan publik dan menjadi faktor pemicu timbulnya konflik.

Satuan Polisi Pamong Praja Pesisir Selatan telah melakukan berbagai upaya penertiban ternak lepas namun belum membawa hasil yang maksimal. Adapun upaya yang dilakukan oleh satuan polisi pamong praja sesuai dengan tugas pokok dan fungsinya sebagai penggerak wujudnya kondisi sosial yang aman, tentram dan tertib adalah:

\section{a. Preventif}

Upaya penertiban yang dilakukan oleh satuan polisi pamong praja Pesisir Selatan berupa pembinaan terhadap pemilik ternak melalui kegiatan sosialisasi dan imbauan yang diberikan secara rutin dan intensif. Bertujuan untuk meningkatkan pemahaman masyarakat terutama peternak lepas dan kesadaran hukumnya terhadap aturan yang berlaku. Pihak satuan polisi 
pamong praja sudah mendata jumlah pemilik ternak di kawasan Batang Kapas, kemudian anggota melakukan tindakan persuasif dengan pemilik ternak membicarakan ketertiban ternak. Selanjutnya pihak satuan polisi pamong praja telah melaksanakan aktivitas seperti sosialisasi larangan ternak lepas, akibat yang ditimbulkan, sanksi dan hukuman yang diberikan pada pelanggar aturan sesuai dengan peraturan daerah No.1 Tahun 2016 serta sistem pemeliharaan ternak yang di kandangkan.

b. Represif

Tindakan penertiban terhadap ternak lepas berupa pengoptimalan kinerja melalui tingkat pengawasan secara berkala dalam bentuk razia atau patroli. Bertujuan untuk menertibkan ternak yang ditemui masih mengganggu masyarakat dan pengguna jalan sehingga terciptalah suatu kondisi lingkungan yang bersih, aman dan sehat bebas dari gangguan ternak lepas. Dilihat dari penelitian di lapangan menunjukkan bahwa upaya represif yang dilakukan oleh pihak satuan polisi pamong praja belum sepenuhnya terlaksana dengan baik. Hal ini dikarenakan petugas hanya beroperasi pada daerah ibu kota kabupaten saja tanpa eksekusi langsung ke tingkat kecamatan yang seharusnya sudah menjadi skop wilayah penertiban. Akan tetapi pihak satuan polisi pamong praja telah melakukan koordinasi yang baik dengan pihak kecamatan untuk melakukan razia ternak lepas di kecamatan Batang Kapas yang kemudian di laporkan pada satuan polisi pamong praja.

c. Penegakan hukuman berupa denda

Pemberlakuan hukuman berupa denda sesuai dengan Peraturan Daerah Nomor 1 Tahun 2016 Pasal 41 tentang penertiban ternak belum sepenuhnya terlaksana karena denda yang diberlakukan baru diterapkan. Akan tetapi pihak satuan polisi pamong praja Pesisir Selatan telah berkoordinasi secara baik dengan pihak kecamatan untuk dapat melakukan eksekusi selanjutnya seperti memberikan teguran dan surat peringatan pada peternak yang telah melanggar aturan.

\section{Kendala Yang Dihadapi oleh Satuan Polisi Pamong Praja Dalam Melakukan Penertiban Ternak Di Kecamatan Batang Kapas}

Dalam pelaksanaan kegiatan penertiban ternak lepas, Satuan Polisi Pamong Praja Kabupaten Pesisir Selatan sangat berperan penting demi terwujudnya pelaksanaan ketentraman masyarakat dan ketertiban umum di Batang Kapas serta dapat mengantisipasi permasalahan yang muncul. Namun demikian ada beberapa kendala yang ditemui oleh satuan polisi pamong praja dalam melakukan penertiban ternak lepas. Kendala tersebut antara lain adalah.

a. Keterbatasan jumlah anggota satuan polisi pamong praja dan ketersediaan sarana dan prasarana yang kurang memadai. Hal ini jelas terlihat bahwa melihat kondisi geografis dan jumlah penduduk di Kecamatan Batang Kapas Kabupaten Pesisir Selatan yang luas menjadi 
salah satu faktor penghambat dari pelaksanaan kegiatan penertiban ternak lepas di lapangan. Saat ini jumlah personil satuan polisi pamong praja berjumlah 49 orang. Sementara itu kendaraan operasional satuan polisi pamong praja hanya ada 1 Truk.

b. Belum maksimalnya pengawasan secara berkala dalam bentuk razia atau patroli terhadap penertiban ternak lepas di Kecamatan Batang Kapas, sementara di lapangan masih ada pelanggaran yang diakibatkan oleh gangguan ternak yang berkeliaran sampai ke jalan raya. Hal ini dibuktikan dari operasi berupa razia atau patroli penertiban ternak yang belum merata di setiap kecamatan.

c. Lahan pengembala ternak sebagai tempat ternak dikumpulkan yang belum ada disediakan, masyarakat meminta pemerintah yang menyediakan lahan untuk ternak dikumpulkan agar tidak berkeliaran di jalan. Tetapi pemerintah tidak mempunyai anggaran dana yang cukup untuk membeli lahan tersebut, maka dari itu sampai saat ini belum ada tempat pengembalaan ternak.

d. Penegakkan hukum yang belum optimal, sesuai dengan Peraturan Daerah No. 1 Tahun 2016 Tentang Ketentraman Masyarakat dan Ketertiban Umum telah memberlakukan hukuman berupa denda di Kabupaten Pesisir Selatan bagi peternak yang melanggar aturan tersebut. Namun pada faktanya Untuk pemberlakuan hukuman berupa denda belum sepenuhnya diterapkan dengan baik, karena keterbatasan waktu untuk melakukan eksekusi langsung ke lapangan belum ada, sehingga masih banyak masyarakat terutama pemilik ternak lepas melakukan pelanggaran.

e. Kemampuan sumber daya manusia masyarakat yang masih rendah, melihat kondisi latar belakang pendidikan dan tingkat sumber daya manusia yang ada di kecamatan Batang Kapas yang masih rendah, membuat mereka tidak berpartisipasi dalam mengikuti kegiatan sosialisasi larangan ternak lepas dan meningkatnya pelanggaran kesehatan lingkungan serta ketidakpeduliannya terhadap aturan yang berlaku.

3. Solusi Yang Dilakukan Oleh Satuan Polisi Pamong Praja Pesisir Selatan Dalam Menanggulangi Kendala Yang Terjadi

Adapun solusi yang seharusnya dilakukan oleh satuan polisi pamong praja dalam menanggulangi kendala dalam pelaksanaan kegiatan penertiban ternak adalah: (1) Memaksimalkan kegiatan sosialisasi secara rutin dan intensif sekaligus memberikan informasi yang jelas kepada masyarakat tentang larangan ternak lepas ke jalan raya dan urgensi sistem pemeliharaan ternak yang dikandangkan (2) Membuat Peraturan bersama terkait dengan eksekusi penertiban ternak melalui Musyawarah Tingkat Kecamatan guna memperkuat Peraturan Daerah No. 1 Tahun 2016 (3) Mengoptimalkan kegiatan pengawasan secara berkala dalam bentuk razia Operasi Tangkap 
Tangan ternak lepas antar kecamatan. (4) Membuat anggaran dana untuk penyediaan lahan pengembala dan kandang yang memadai (5) Memaksimalkan Sumber daya anggota satuan polisi pamong praja dan berkoordinasi secara efektif dan komunikatif dengan pihak kecamatan sekaligus anggota swadaya masyarakat lainnya.

\section{KESIMPULAN DAN SARAN Kesimpulan}

Berdasarkan pembahasan yang dikaji oleh peneliti maka dapat disimpulkan beberapa hal sebagai berikut:

1. Bentuk upaya satuan polisi pamong praja dalam penertiban ternak di Kecamatan Batang Kapas Kabupaten Pesisir Selatan belum terlaksana dengan baik. Hal ini terlihat jelas dari hasil penelitian yang menerangkan bahwa pelaksanaan kegiatan penertiban ternak berupa sosialisasi serta memberikan informasi yang jelas sudah dilakukan. Namun eksekusi langsung dari satuan polisi pamong praja belum terlaksana sesuai dengan rencana dan tujuan yang telah direncanakan.

2. Kendala yang dihadapi oleh satuan polisi pamong praja dalam penertiban ternak di Kecamatan Batang Kapas adalah tingkat kemampuan sumber daya manusia yang masih rendah serta minimnya kesadaran hukum masyarakat pada aturan yang berlaku, belum maksimalnya sosialisasi yang diberikan oleh pihak terkait, ketersediaan lahan pengembala ternak dan kandang terbatas, belum adanya pengawasan secara berkala dalam bentuk razia antar kecamatan serta eksekusi tegas dari pihak Satpol PP Pesisir Selatan belum terlaksana dengan baik.

3. Upaya yang dilakukan dalam mengatasi kendala yang terjadi adalah pihak pemerintah Kabupaten Pesisir Selatan bersama Dinas Satuan Polisi Pamong Praja dan Pemadam Kebakaran Kabupaten Pesisir Selatan harus mengadakan sosialisasi larangan ternak lepas tiap tahunnya pada masyarakat atau pemilik ternak, membuat Peraturan bersama terkait dengan eksekusi penertiban ternak melalui Musyawarah Tingkat Kecamatan guna memperkuat Peraturan Daerah No. 1 Tahun 2016, mengadakan razia ternak lepas antar kecamatan memberikan eksekusi tegas dan nyata terutama pada penerapan sanksi dan hukum berupa denda, menyediakan lahan dan kandang yang memadai, serta mengajak perangkat desa untuk berkoordinasi secara efektif dalam rangka mewujudkan pelaksanaan Peraturan Daerah No. 1 Tahun 2016 tentang ketentraman masyarakat dan ketertiban umum sebagaimana yang sudah

\section{Saran} ditetapkan.

Berdasarkan hasil penelitian dan pembahasan yang dipaparkan ada beberapa saran perbaikan yang diberikan antara lain adalah: 
1. Bagi Satuan Polisi Pamong Praja Kabupaten Pesisir Selatan, agar lebih meningkatkan kinerjanya dalam penertiban ternak lepas dan bisa meningkatkan koordinasi yang baik dengan aparat setempat agar upaya preventif, represif, dan penegakan hukum berupa denda dapat terlaksana dengan maksimal.

2. Penyediaan Standar Operasional Prosedur Satuan Polisi Pamong Praja yang jelas terutama pada bidang ketentraman masyarakat dan ketertiban umum sekaligus penegak perda dapat terarah, sistematis dan sesuai dengan pencapaian tugas pokok dan fungsi yang telah diatur sebagaimana mestinya.

3. Membudidayakan Slogan "Lingkungan Bersih, Ternak Teratur" dapat memperkuat pelaksanaan Peraturan Daerah No.1 Tahun 2016 karena dengan demikian bisa membuat pemilik ternak lepas sadar dan patuh pada aturan yang telah ditetapkan. Sehingga terciptalah kondisi yang aman, bersih dan teratur "bebas dari gangguan ternak lepas".

\section{Acknowledgement}

Penelitian ini dapat terlaksana secara maksimal berkat bantuan moril yang diberikan pada saat melakukan penelitian bersama Pimpinan Satuan Polisi Pamong Praja Pesisir Selatan beserta Pihak Kecamatan Batang Kapas yang telah memberikan data akurat terkait dengan permasalahan yang diteliti. Sehingga hasil penelitian yang dipaparkan dapat bermanfaat bagi semua pihak sekaligus menjadi salah satu referensi belajar yang jelas.

\section{DAFTAR PUSTAKA}

\section{Buku}

Gautama, Sudargo. 2008. Hukum Perdata Internasional Indonesia. Bandung: Penerbit Alumni.

Poerwadarminta, Suryadi. 2003. Kamus Besar Bahasa Indonesia. Jakarta: Bumi Pustaka.

\section{Peraturan Perundang- Undangan}

Peraturan Pemerintah tentang Satuan Polisi Pamong Praja, PP No. 6 Tahun 2010, Lembaran Negara Republik Indonesia (LNRI) Tahun 2010 Nomor 9, dan Tambahan Lembaran Negara (TLN) Nomor 5094.

Undang-Undang Pemerintah Daerah, UU No. 23 Tahun 2014, Lembaran Negara Republik Indonesia (LNRI) Tahun 2014 Nomor 244 dan Tambahan Lembaran Negara (TLN) Nomor 5587. 
Peraturan Daerah No. 1 Tahun 2016 Tentang Ketentraman Masyarakat dan Ketertiban Umum.

\section{Jurnal}

Nalle, Victor Imanuel W. 2016. Studi Sodio-Legal Terhadap Ketertiban Dan Ketentraman di Kabupaten Sidorjo. Jurnal Hukum \& Pembangunan 47 No.3: 233-22 ISSN: 0125-9687.

Wahyuni, Sri. 2014. Konsep Ketertiban Umum dalam Hukum Perdata Internasional: Perbandingan Beberapa Negara Civil Law dan Common Law. Jurnal Supremasi Hukum. Vol. 3, No. 1

\section{Skripsi}

Sukmawati, Nur.2015.Implementasi Peraturan Daerah No 23 Tahun 2007 Tentang Penertiban Dan Pemeliharaan Ternak Di Kabupaten Sarolangun. Skripsi Mahasiswa Ilmu Administrasi Negara Fakultas Ilmu Sosial Universitas Negeri Padang. Sumatera Barat. 